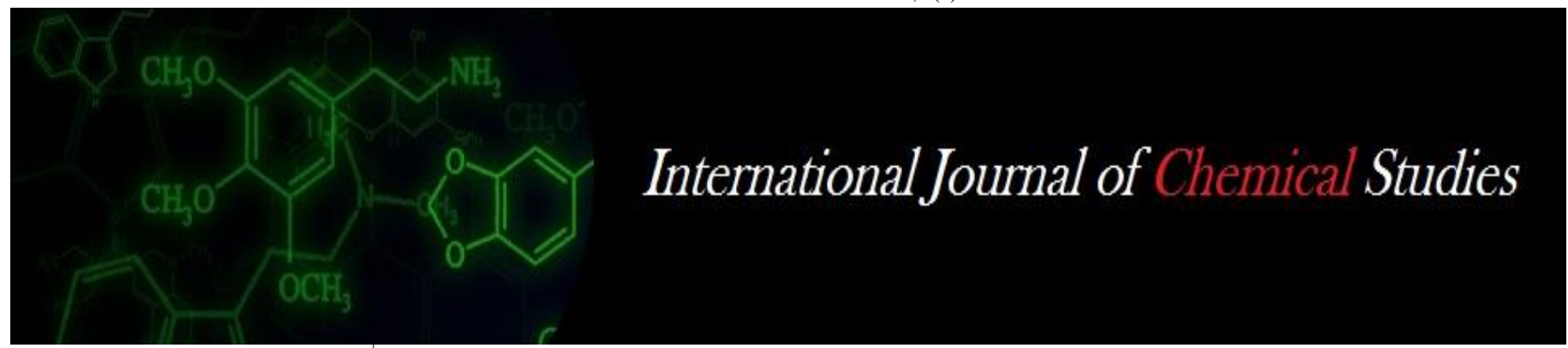

P-ISSN: 2349-8528

E-ISSN: 2321-4902

www.chemijournal.com

IJCS 2021; 9(1): 3568-3573

(C) 2021 IJCS

Received: 01-10-2020

Accepted: 07-12-2020

Sandeep L Badgujar

Vasantrao Naik Marathwada

Krishi Vidyapeeth, Parbhani,

Maharashtra, India

Pawan K Dhoke

Vasantrao Naik Marathwada

Krishi Vidyapeeth, Parbhani,

Maharashtra, India

Manjusha J Shiradkar

Vasantrao Naik Marathwada

Krishi Vidyapeeth, Parbhani,

Maharashtra, India

Sagar Jagdhane

Vasantrao Naik Marathwada

Krishi Vidyapeeth, Parbhani,

Maharashtra, India
Corresponding Author: Sandeep L Badgujar

Vasantrao naik Marathwada

Krishi Vidyapeeth, Parbhani,

Maharashtra, India

\section{To evaluate in vitro the efficacy of fungicides, bio- control agents and plant extract against Colletotrichum capsici}

\author{
Sandeep L Badgujar, Pawan K Dhoke, Manjusha J Shiradkar and Sagar \\ Jagdhane
}

DOI: https://doi.org/10.22271/chemi.2021.v9.i1ax.11787

\begin{abstract}
Colletotrichum capsici infection will be higher in the mature stage of chilli plant than in the early stage of plant (Krairuan et al., 2008). The fungus prefers warm humid environment for spreading the anthracnose disease uniformly and effectively. All the two contact and six systemic fungicides evaluated in vitro were found fungistatic against Colletotrichum capsici. Among all these fungicides, Tricyclazole was found to be most effective with significantly maximum mycelial growth inhibition and least mycelial growth followed by fungicides viz. Azostrobin, Tebuconazole, Difenconazole, Propiconazole, Carbendazim + Mancozeb. While comparatively minimum average radial mycelial growth inhibition was recorded with Hexaconazole followed by Propineb. All the seven fungal and one bacterial antagonists evaluated in vitro were found antifungal against Colletotrichum capsici exhibited significant mycelial growth inhibition. However, Trichoderma asperallum, Pseudomonas fluorescens, Trichoderma harzianum and Gliocladium virens recorded significantly highest mycelial growth inhibition. Rest of the bioagents, Trichoderma ligronum, Trichoderma koningii and Trichoderma longibrachiatum and Trichoderma hamatum tested also caused significant mycelial inhibition of the test pathogen.
\end{abstract}

Keywords: Colletotrichum capsici, efficacy of fungicides, in vitro

\section{Introduction}

Chilli crop is affected by several fungal, bacterial and viral diseases: (Anand et al., 2009). Among the major fungal diseases; Damping off (Pythium aphanidermatum), Powdery mildew (Leveillula taurica), Anthracnose or fruit rot (Colletotrichum capsici) and Cercospora leaf spot (Cercospora capsici) are the major diseases. The important bacterial diseases includes; Bacterial wilt (Ralstonia solanacearum), Leaf spot (Xanthomonas vesicatoria), nematode diseases like Root knot and Root gall caused by Meloidogyne spp. and viral diseases like Chilli mosaic, leaf roll and leaf curl. Among the large number of diseases affecting chilli cultivation, anthracnose disease caused by Colletotrichum species, bacterial wilt by Psuedomonas solanacearum and viral diseases like chilli mosaic virus (CMV) infection have been most detrimental to chilli production.

Anthracnose of chilli was first reported from New Jersey, USA, described the causal agents as Gloeopsorium piperatum and Colletotrichum nigrum. These taxa were then considered as synonyms of Colletotrichum gloeosporiodes heavy crop losses worldwide. Specifically, Colletotrichum is an asexual genus belonging to phylum Ascomycete and Coeleomycetes class of Fungi imperfectii. The disease has been reported from many countries including India, United States of America, Nigeria, Bangladesh and Indonesia. Anthracnose disease is a major problem in India and first reported in India from Coimbatore of Madras Presidency. These disease caused by more than one Colletotrichum species including; Colletotrichum acutatum, Colletotrichum capsici, Colletotrichum gloeosporioides and Colletotrichum coccodes. Colletotrichum capsici infection will be higher in the mature stage of chilli plant than in the early stage of plant. The fungus prefers warm humid environment for spreading the anthracnose disease uniformly and effectively. The fungus is primarily invades into injured or weakened tissues of plants, produces various specialized structures during infection process. 
In tropical countries, high moisture condition due to monsoon rain during June-October favors sporulation of Colletotrichum capsici which enhances the fruit rot disease incidence and helps outbreak of the disease. Hence, the objective of present study was to evaluate in vitro the efficacy of fungicides, biocontrol agents and plant extract against Colletotrichum capsici.

\section{Material and Methods \\ In vitro evaluation of fungicides \\ Experimental details \\ Design: C.R.D. \\ Replications: Three \\ Treatments: Nine}

Table 1: Treatment details

\begin{tabular}{|c|c|c|c|}
\hline Sr. No. & Common Name & Trade Name & Concentration \\
\hline $\mathrm{T}_{1}$ & $\begin{array}{c}\text { Carbendazim }+ \\
\text { Mancozeb }\end{array}$ & Saaf 75 WP & $0.05 \%, 0.1 \% 0.2 \%$ \\
\hline $\mathrm{T}_{2}$ & Propineb & Antracol 70 WP & $0.05 \%, 0.1 \% 0.2 \%$ \\
\hline $\mathrm{T}_{3}$ & Hexaconazole & Contaf 5\% EC & $0.025 \%, 0.05 \% 0.1 \%$ \\
\hline $\mathrm{T}_{4}$ & Propiconazole & Tilt 25 EC & $0.025 \%, 0.05 \% 0.1 \%$ \\
\hline $\mathrm{T}_{5}$ & Difenconazole & Score 25 EC & $0.025 \%, 0.05 \% 0.1 \%$ \\
\hline $\mathrm{T}_{6}$ & Tebuconazole & Folicur 25 EC & $0.025 \%, 0.05 \% 0.1 \%$ \\
\hline $\mathrm{T}_{7}$ & Azoxystrobin & Amistar 25 EC & $0.025 \%, 0.05 \% 0.1 \%$ \\
\hline $\mathrm{T}_{8}$ & Tricyclazole & Beam 75\%WP & $0.025 \%, 0.05 \% 0.1 \%$ \\
\hline $\mathrm{T}_{9}$ & Control & & \\
\hline
\end{tabular}

Observations on radial mycelial growth of the test fungus were recorded at $24 \mathrm{hrs}$ interval and continued till growth of the test pathogen in untreated control plate was fully covered. Per cent inhibition of the test pathogen was calculated by applying the formula.

Per cent inhibition $(R)=\frac{C-T}{C}$

Where,

$\mathrm{C}=$ Growth of the test fungus in untreated control plates. $\mathrm{T}=$ Growth of the test fungus in treated plates.

\section{In vitro evaluation of bioagents \\ Experimental Details : Design \\ : C.R.D. \\ Replications : : Three \\ Treatments : Nine}

Table 2: Treatment details

\begin{tabular}{|c|c|}
\hline Tr. No. & Treatments \\
\hline $\mathrm{T}_{1}$ & Trichoderma asperallum \\
\hline $\mathrm{T}_{2}$ & Trichoderma harzianum \\
\hline $\mathrm{T}_{3}$ & Trichoderma hamatum \\
\hline $\mathrm{T}_{4}$ & Pseudomonas fluorescens \\
\hline $\mathrm{T}_{5}$ & Trichoderma ligronum \\
\hline $\mathrm{T}_{6}$ & Trichoderma koningii \\
\hline $\mathrm{T}_{7}$ & Trichoderma longibrachiatum \\
\hline $\mathrm{T}_{8}$ & Gliocladium virens \\
\hline $\mathrm{T}_{9}$ & Control \\
\hline
\end{tabular}

Observations on linear mycelial growth of the test pathogen and test bioagent were recorded at an interval of 24 hours, continued till untreated control plates were fully covered with mycelial growth of the test pathogen and averaged finally. Per cent inhibition of the test pathogen was calculated by applying the formula.

Where,

Per cent inhibition $(\mathrm{R})=\frac{\mathrm{C}-\mathrm{T}}{\mathrm{C}}$

$\mathrm{C}=$ Growth of the test fungus in untreated control plates.

$\mathrm{T}=$ Growth of the test fungus in treated plates.

In vitro evaluation of botanicals (plant extracts)

Experimental details

$\begin{array}{ll}\text { Design } & : \text { C.R.D. } \\ \text { Replication } & : \text { Three } \\ \text { Treatment } & : \text { Eight } \\ \mathrm{T}_{1} & : \text { karanj (Leaves extract) } \\ \mathrm{T}_{2} & : \text { Onion (Bulbextract) } \\ \mathrm{T}_{3} & : \text { Garlic (Bulbextract) } \\ \mathrm{T}_{4} & : \text { Turmeric (Rhizome extract) } \\ \mathrm{T}_{5} & : \text { Neem (Leaves extract) } \\ \mathrm{T}_{6} & : \text { Ginger (Rhizome extract } \\ \mathrm{T}_{7} & : \text { Tulsi (Leaves extract) } \\ \mathrm{T}_{8} & : \text { Control (Untreated). }\end{array}$

Observations on radial mycelial growth of the test fungus were recorded at $24 \mathrm{hrs}$ interval and continued till growth of the test pathogen in untreated control plate was fully covered. Per cent inhibition of the test pathogen was calculated by applying the formula.

Per cent inhibition $(R)=\frac{C-T}{C}$

Where,

$\mathrm{C}=$ Growth of the test fungus in untreated control plates.

$\mathrm{T}=$ Growth of the test fungus in treated plates.

\section{Results and Discussion}

In vitro efficacy of fungicides

A total 8 fungicide evaluated in vitro against Colletotrichum capsici exhibited a wide range of mycelial growth and inhibition of the test pathogen. The results obtained are presented in the Table- 1 and depicted in Fig.- 3 and PLATE-5 (A).

\section{Radial mycelial growth}

Results (Table 1, Fig 1, Plate 5 B) indicated that the mycelial growth of Colletotrichum capsici was significantly differed with all the contact fungicides evaluated at $0.05 \%, 0.1 \%$ and $0.2 \%$ and systemic fungicides $0.025 \%, 0.05 \%$ and $0.1 \%$. (Table 1, Fig 3, Plate 5 B).

Systemic fungicides at $0.25 \%$ and contact fungicides at $0.05 \%$, radial mycelial growth of the test pathogen were ranged from $20.00 \mathrm{~mm}$ (Tricyclazole) to $53.33 \mathrm{~mm}$ (Propineb). However, significantly least mycelial growth was recorded with the fungicide Tricyclazole $(20.00 \mathrm{~mm})$ followed by the fungicides viz Azoxystrobin $(24.00 \mathrm{~mm}$ ), Difenconazole $(26.33 \mathrm{~mm})$, Tebuconazole $(27.66 \mathrm{~mm})$, Propiconazole (31.66 mm), Carbendazim + Mancozeb (36.00 $\mathrm{mm})$ and Hexaconazole $(39.66 \mathrm{~mm})$ which were at par with 
each other. Whereas, comparatively maximum radial mycelial growth was recorded with Propineb $(53.33 \mathrm{~mm})$.

Systemic fungicides at $0.05 \%$ and contact fungicides at $0.1 \%$, radial mycelial growth of the test pathogen were ranged from $18.66 \mathrm{~mm}$ (Tricyclazole) to $36.33 \mathrm{~mm}$ (Propineb). However, significantly least mycelial growth was recorded with the fungicide Tricyclazole $(18.66 \mathrm{~mm})$ followed by the fungicides viz Tebuconazole $(21.00 \mathrm{~mm})$, Azoxystrobin $(22.66 \mathrm{~mm})$, Difenconazole $(25.00 \mathrm{~mm})$, Propiconazole $(29.33 \mathrm{~mm})$, Carbendazim + Mancozeb $(33.00 \mathrm{~mm})$ which were at par with each other. Whereas, comparatively maximum radial mycelial growth was recorded with Propineb $(36.33 \mathrm{~mm})$.
Systemic fungicides at $0.1 \%$ and contact fungicides at $0.2 \%$, radial mycelial growth of the test pathogen were ranged from $9.66 \mathrm{~mm}$ (Azostrobin) to $31.00 \mathrm{~mm}$ (Propineb and Hexaconazole). However, significantly least mycelial growth was recorded with the fungicide Azoxystrobin $(9.66 \mathrm{~mm})$ followed by the fungicides viz Tebuconazole $(12.66 \mathrm{~mm})$, Tricyclazole $(15.00 \mathrm{~mm})$ Propiconazole $(18.00 \mathrm{~mm})$, Difenconazole $(22.00 \mathrm{~mm})$ and Carbendazim + Mancozeb $(23.33 \mathrm{~mm})$ which were at par with each other. Whereas, comparatively maximum radial mycelial growth was recorded with Propineb and Hexaconazole $(31.00 \mathrm{~mm})$. Pathogen. The results obtained are presented in the Table- 3 and depicted in Fig. and PLATE.

Table 3: In vitro efficacy of fungicides against mycelial growth and inhibition of Colletotrichum capsici

\begin{tabular}{|c|c|c|c|c|c|c|c|c|c|}
\hline \multirow{2}{*}{ Tr. No. } & \multirow{2}{*}{ Treatments } & \multicolumn{3}{|c|}{ Colony Dia. *(mm) at Percentage } & \multirow{2}{*}{ Av. $(\mathbf{m m})$} & \multicolumn{3}{|c|}{ \% Inhibition* at Percentage } & \multirow{2}{*}{ Av. inhibition (\%) } \\
\hline & & 0.05 & \begin{tabular}{|l|l|}
0.1 \\
\end{tabular} & 0.2 & & 0.05 & 0.1 & 0.2 & \\
\hline $\mathrm{T}_{1}$ & $\begin{array}{l}\text { Carbendazim } \\
+ \text { Mancozeb }\end{array}$ & $36.00(36.86)$ & $33.00(35.06)$ & $23.33(28.88)$ & $30.77(33.69)$ & $60.00(50.76)$ & $63.3(57.73)$ & $74.07(59.38)$ & $65.80(54.21)$ \\
\hline $\mathrm{T}_{2}$ & Propineb & $53.33(46.90)$ & $36.33(37.06)$ & $31.00(33.83)$ & $40.22(39.36)$ & $40.74(39.66)$ & $59.63(50.55)$ & $65.55(54.05)$ & $55.30(48.04)$ \\
\hline & & 0.025 & 0.05 & 0.1 & & 0.025 & 0.05 & 0.1 & \\
\hline $\mathrm{T}_{3}$ & Hexaconazole & $39.66(39.03)$ & $33.33(35.26)$ & $31.00(33.83)$ & $34.66(36.06)$ & $55.93(48.40)$ & $62.96(52.51)$ & $65.55(54.05)$ & $61.48(51.63)$ \\
\hline $\mathrm{T}_{4}$ & Propiconazole & $31.66(34.24)$ & $29.33(32.79)$ & $18.00(25.10)$ & $26.33(30.87)$ & $64.82(53.62)$ & $67.41(55.18)$ & $80.00(63.43)$ & $70.74(57.25)$ \\
\hline $\mathrm{T}_{5}$ & Difenconazole & $26.33(30.87)$ & $25.00(30.00)$ & $22.00(27.97)$ & $24.44(29.62)$ & $70.74(57.25)$ & $72.22(58.19)$ & $75.55(66.36)$ & $72.83(58.58)$ \\
\hline $\mathrm{T}_{6}$ & Tebuconazole & $27.66(31.73)$ & $21.00(27.27)$ & $12.66(20.84)$ & $20.44(26.87)$ & $69.26(56.32)$ & $76.66(61.11)$ & $85.93(67.96)$ & $77.28(61.53)$ \\
\hline $\mathrm{T}_{7}$ & Azoxystrobin & $24.00(29.33)$ & $22.66(28.42)$ & $9.66(18.10)$ & $18.77(25.67)$ & $73.33(38.90)$ & $74.82(59.88)$ & $89.26(70.86)$ & $79.13(62.81)$ \\
\hline $\mathrm{T}_{8}$ & Tricyclazole & $20.00(26.54)$ & $18.66(25.59)$ & $15.00(22.78)$ & $17.88(25.01)$ & $77.77(61.86)$ & $79.26(76.26)$ & $83.33(65.90)$ & $80.12(63.52)$ \\
\hline $\mathrm{T}_{9}$ & Control & $90.00(71.56)$ & $90.00(71.56)$ & $90.00(71.56)$ & $90.00(71.56)$ & 00.00 & 00.00 & 00.00 & 00.00 \\
\hline & S.E.t & 5.79 & 4.06 & 0.82 & & 0.63 & 0.54 & 0.72 & -- \\
\hline & \begin{tabular}{|l|} 
C.D. $(\mathrm{P}=0.01)$ \\
\end{tabular} & 1.93 & 1.35 & 2.46 & & 1.91 & 1.63 & 2.15 & -- \\
\hline
\end{tabular}

*: Mean of three replications, Dia: Diameter. Figures in parenthesis are arc sine transformed value

\section{Plate}

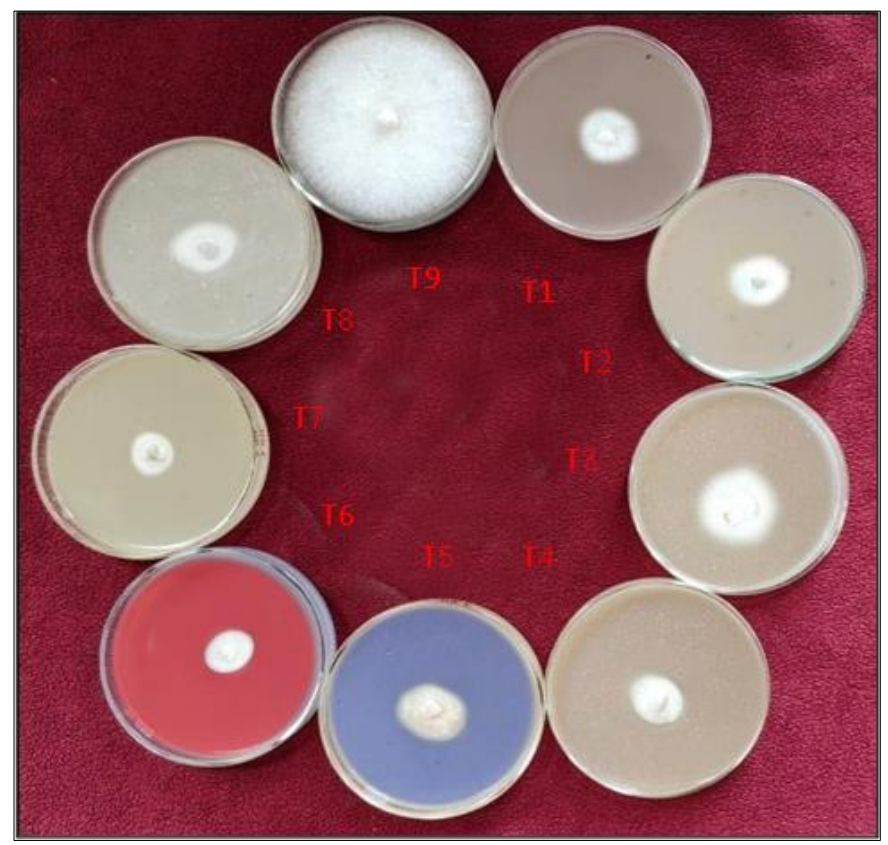

(A) $0.1 \%$

T1: Carbendazim 25\%+Mancozeb 50\%

T2: Propineb25 EC

T3: Hexaconzole

T4: Propiconazole

T5: Difenconazole

T6: Tebuconazole

T7: Azoxystrobin

T8: Tricyclazole

T9: Control
In vitro efficacy of fungicides on radial mycelial growth and inhibition of Colletotrichum capsici Plate

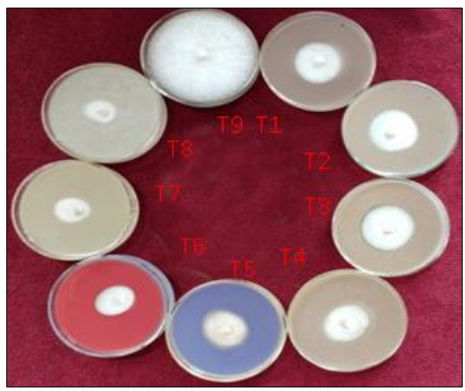

(A) $0.05 \%$

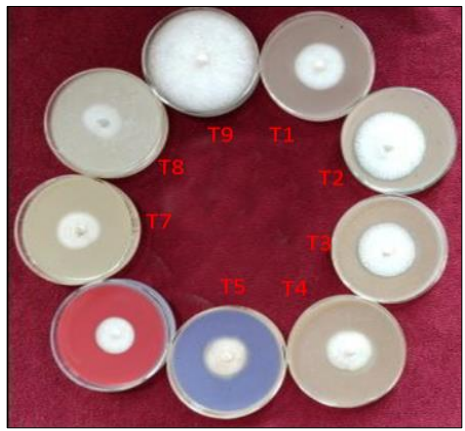

(B) $0.025 \%$,

T1: Carbendazim 25\%+Mancozeb 50\%

T2: Propineb25 EC

T3: Hexaconzole

T4: Propiconazole

T5: Difenconazole 
T6: Tebuconazole

T7: Azoxystrobin

T8: Tricyclazole

T9: Control

\section{Mycelial growth inhibition}

The results (Table and Fig.) indicated that all contact fungicides evaluated at $0.05 \%, 0.1 \%$ and $0.2 \%$ and systemic fungicides $0.025 \%, 0.05 \%$ and $0.1 \%$ which significantly inhibited mycelial growth of the test fungus over untreated control $(00.00 \%)$.

Further, it was found that percentage growth inhibition was increased with the increase in concentrations of the fungicides tested (PLATE). Systemic fungicides at $0.025 \%$ and contact fungicides at $0.05 \%$, percentage mycelial growth inhibition were ranged from $40.74 \%$ (Propineb) to $77.77 \%$ (Tricyclazole). However, significantly highest percentage of mycelial growth inhibition was recorded with Tricyclazole $77.77 \%$. This was followed by the fungicides viz., Azoxystrobin (73.33\%) Difenconazole $(70.74 \%)$, Tebuconazole (69.26\%), Propiconazole (64.82\%), Carbendazim + Mancozeb $(60.00 \%)$ and Hexaconazole (55.93\%). Whereas, comparatively least percentage of mycelial growth inhibition was recorded with Propineb $(40.74 \%)$. Systemic fungicides at $0.05 \%$ and contact fungicides at 0.1 percentage, mycelial growth inhibition was ranged from $79.26 \%$ (Tricyclazole) to $59.63 \%$ (Propineb). However, significantly highest percentage of mycelial growth inhibition was recorded with Tricyclazole $(79.26 \%)$ followed by the fungicides viz Tebuconazole (76.66\%), Azoxystrobin (74.82\%), Difenconazole (72.22\%), Propiconazole (67.41\%), Carbendazim + Mancozeb (63.33\%) and Hexaconazole $(62.96 \%)$. Whereas, comparatively least percentage of mycelial growth inhibition was recorded with Propineb $(59.63 \%)$.

Systemic fungicides at $0.1 \%$ and contact fungicides at $0.2 \%$, mycelial growth inhibition were ranged from $89.26 \%$ (Azostrobin) to $65.55 \%$ (Propineb and Hexaconazole). However, Significantly highest percentage of mycelial growth inhibition was recorded with Azoxystrobin (89.26\%) followed by the fungicides viz Tebuconazole (85.93\%), Tricyclazole $(83.33 \%)$, Propiconazole $(80.00 \%)$, Difenconazole $(75.55 \%)$ and Carbendazim + Mancozeb (74.07\%) Whereas, comparatively least percentage of mycelial growth inhibition was recorded with Propineb and Hexaconazole (65.55\%).

The present results are also in agreement with the results obtained by Hegde et al., (2002b) tested the efficacy of three triazole fungicides viz., Hexaconazole $(0.1 \%)$, Propiconazole $(0.1 \%)$ and Triadimefon $(0.1 \%)$ against fruit rot pathogen Colletotrichum capsici by poison food technique and reported that significant inhibition of mycelial growth was recorded with all three fungicides.

\section{In vitro evaluation of bioagents/ antagonists}

The results obtained on mycelial growth and inhibition Colletotrichum capsici with seven fungal and one bacterial antagonists are presented in (Table, Fig. and PLATE).

Table 4: In vitro efficacy of different bioagents against mycelial growth and inhibition of Colletotrichum capsici

\begin{tabular}{|c|c|c|c|}
\hline Tr. No. & Treatments & Colony Dia. of test pathogen * $(\mathbf{m m})$ & \% Inhibition \\
\hline $\mathrm{T}_{1}$ & Trichoderma asperallum & $17.00(24.35)$ & $81.11(64.23)$ \\
\hline $\mathrm{T}_{2}$ & Trichoderma harzianum & $26.65(31.08)$ & $70.38(57.02)$ \\
\hline $\mathrm{T}_{3}$ & Trichoderma hamatum & $45.00(42.13)$ & $50.00(45.00)$ \\
\hline $\mathrm{T}_{4}$ & Pseudomonas fluorescens & $23.00(28.65)$ & $74.44(59.63)$ \\
\hline $\mathrm{T}_{5}$ & Trichoderma ligronum & $32.66(34.85)$ & $63.71(52.95)$ \\
\hline $\mathrm{T}_{6}$ & Trichoderma koningii & $41.66(40.19)$ & $53.71(47.12)$ \\
\hline $\mathrm{T}_{7}$ & Trichoderma longibrachiatum & $43.33(41.16)$ & $51.85(46.06)$ \\
\hline $\mathrm{T}_{8}$ & Gliocladium virens & $28.66(32.36)$ & $68.15(55.64)$ \\
\hline $\mathrm{T}_{9}$ & Control & $90.00(71.56)$ & 00.00 \\
\hline & S.E. + & 1.75 & 0.54 \\
\hline & C.D. $(\mathrm{P}=0.01)$ & 5.23 & 1.63 \\
\hline
\end{tabular}

*Mean of three replications. Dia: Diameter. Figures in parenthesis are arc sine transformed value

The results are presented in Table, Plate and depicted graphically in Fig 4.-revealed that, all the antagonists tested against Colletotrichum capsici were effective in checking the growth of the pathogen. Out of eight antagonists tested, least mycelial growth of the test pathogen was recorded in Trichoderma asperallum $(17.00 \mathrm{~mm})$ which was at par with Pseudomonas fluorescens $(23.00 \mathrm{~mm})$ followed by Trichoderma harzianum $(26.65 \mathrm{~mm})$, Gliocladium virens (28.66 mm), Trichoderma ligronum (32.66 $\mathrm{mm})$, Trichoderma koningii (41.66 $\mathrm{mm})$ and Trichoderma longibrachiatum $(43.33 \mathrm{~mm})$ while maximum growth recorded with Trichoderma hamatum $(45.00 \mathrm{~mm})$.

The result presented in Table-4 revealed that, Trichoderma asperallum (81.11\%), Pseudomonas fluorescens (74.44\%), Trichoderma harzianum (70.38\%) Gliocladium virens (68.15\%), Trichoderma ligronum $(63.71 \%)$ and Trichoderma koningii $(53.71 \%)$ significantly inhibited the pathogen. whereas, Trichoderma longibrachiatum (51.85\%) and Trichoderma hamatum (50.00\%) recorded least effective. It is evident from these studies that among all the antagonists evaluated by dual culture method, Trichoderma asperallum, Pseudomonas fluorescens and Gliocladium virens consistently showed strong antagonistic property against $C$. capsici compared to the other antagonists tested hence considered as potential antagonists.

\section{Plate}

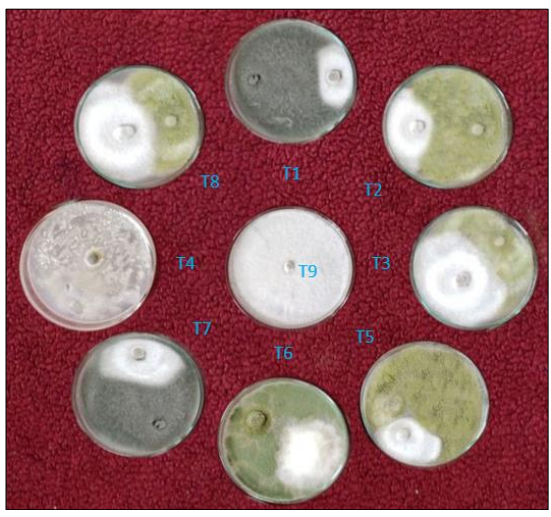




$\begin{array}{ll}\mathrm{T}_{1}: & \text { T. asperallum } \\ \mathrm{T}_{2}: & \text { T. harzianaum } \\ \mathrm{T}_{3} ; & \text { T. hamatum } \\ \mathrm{T}_{4}: & \text { Pseudomonas fluorescens } \\ \mathrm{T}_{5}: & \text { T. lignorum } \\ \mathrm{T}_{6}: & \text { T. Koningii } \\ \mathrm{T}_{7}: & \text { T. longibrachiatum } \\ \mathrm{T}_{8}: & \text { Gliocladium virens } \\ \mathrm{T}_{9}: & \text { Control }\end{array}$

In vitro efficacy of bioagents on mycelial growth and inhibition of Colletotrichum

In vitro evaluation of plant extracts / botanicals: In present studies total botanicals were tested for their efficacy against Colletotrichum capsici at $15 \%$ and $20 \%$ concentration by employing poisoned food technique and data are presented in (Table, Fig, and Plate). Results revealed that all the botanicals tested were effective in inhibiting mycelial growth of Colletotrichum capsici over untreated control.

Table 5: In vitro efficacy of different botanicals/plant extract against mycelial growth and inhibition of Colletotrichum capsici

\begin{tabular}{|c|c|c|c|c|c|c|c|}
\hline \multirow{2}{*}{ Tr. No. } & \multirow{2}{*}{ Treatments } & \multicolumn{2}{|c|}{ Colony Diameter $(\mathrm{mm})^{*}$} & \multirow{2}{*}{ Ave. $(\mathrm{mm})$} & \multicolumn{2}{|c|}{ \% Inhibition at Conc. } & \multirow{2}{*}{ Ave. $(\mathrm{mm})$} \\
\hline & & @ 15\% Concentration & @ 20\% Concentration & & @15\% & @ 20\% & \\
\hline $\mathrm{T}_{1}$ & Karanj & $66.00(54.33)$ & $45.66(42.51)$ & $55.83(48.34)$ & $26.66(31.08)$ & $49.26(44.57)$ & $37.96(38.03)$ \\
\hline $\mathrm{T}_{2}$ & Onion & $36.66(37.26)$ & $33.00(35.06)$ & $34.83(36.16)$ & $59.26(50.33)$ & $63.33(52.73)$ & $61.29(51.52)$ \\
\hline $\mathrm{T}_{3}$ & Garlic & $47.33(43.46)$ & $20.00(26.56)$ & $33.66(35.46)$ & $47.41(43.51)$ & $77.77(61.86)$ & $62.59(52.29)$ \\
\hline $\mathrm{T}_{4}$ & Turmeric & $30.00(33.21)$ & $11.00(19.36)$ & $20.50(26.92)$ & $66.66(54.73)$ & $87.77(69.53)$ & $77.21(61.48)$ \\
\hline $\mathrm{T}_{5}$ & Neem & $21.00(27.27)$ & $17.00(24.35)$ & $19.00(25.84)$ & $76.66(6.11)$ & $81.11(64.23)$ & $78.88(62.64)$ \\
\hline $\mathrm{T}_{6}$ & Ginger & $41.00(39.81)$ & $31.33(34.03)$ & $36.16(36.96)$ & $54.44(47.54)$ & $65.18(53.83)$ & $59.81(50.65)$ \\
\hline $\mathrm{T}_{7}$ & Tulsi & $43.00(40.97)$ & $29.32(32.78)$ & $36.16(36.96)$ & $52.22(46.27)$ & $67.42(55.19)$ & $59.81(50.65)$ \\
\hline $\mathrm{T}_{8}$ & Control & $90.00(71.56)$ & $90.00(71.56)$ & $90.00(71.56)$ & 00.00 & 00.00 & 00.00 \\
\hline \multicolumn{2}{|c|}{ S.E. +} & 4.24 & 4.37 & & 0.54 & 0.533 & \\
\hline \multicolumn{2}{|c|}{ C.D. $(\mathrm{P}=0.05)$} & 1.40 & 1.44 & & 1.65 & 1.61 & \\
\hline
\end{tabular}

*: Mean of three replications, Dia: Diameter

Figures in parenthesis are arc sine transformed value

At $15 \%$ concentration out of seven botanicals tested the Neem leaf extract was found to be most effective and recorded least mycelial growth $(21.00 \mathrm{~mm})$ with highest percent mycelial inhibition (76.66\%) of Colletotrichum capsici and statistically significant over rest of the botanicals followed by Turmeric rhizome extract which recorded

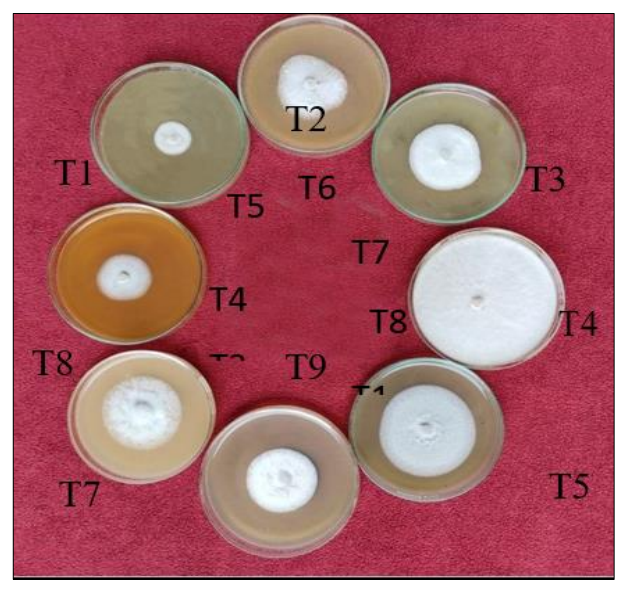

(A) @ $15 \%$

\section{Plate VIII}

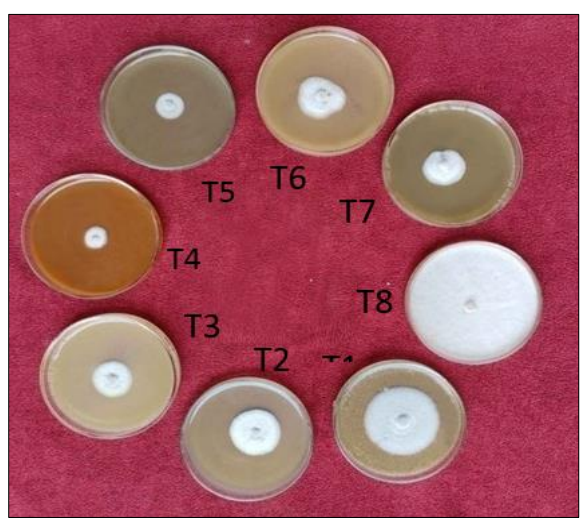

(C) @ 20\%
In vitro efficacy of plant extract/botanicals at (A) $15 \%$, (B) $20 \%$ on growth and inhibition of Colletotrichum

Diameter and percent mycelial inhibition of $30.00 \mathrm{~mm}$ and $(66.66 \%)$ and statistically significant over rest of the botanicals. Onion bulb extract recorded colony diameter of $36.66 \mathrm{~mm}$ and corresponding inhibition of $59.26 \%$ and statistically at par with Ginger extract $(41.00 \mathrm{~mm}$ and $36.16 \%$ ). It was statistically significant over rest of the botanicals. The Tulsi leaf extract $(43.00 \mathrm{~mm}$ and $52.22 \%)$ was statistically at par with Garlic clove extract which recorded $47.33 \mathrm{~mm}$ colony diameter and $47.41 \%$ inhibition. Karanj leaf extracts which recorded minimum colony diameter which was $66.00 \mathrm{~mm}$ and $26.66 \%$ mycelial growth inhibition. The untreated control plates recorded maximum colony diameter i.e.; $(90.00 \mathrm{~mm})$.

At $20 \%$ concentration out of seven botanicals tested the Turmeric Rhizome extract was found to be most effective and recorded least mycelial growth $(11.00 \mathrm{~mm})$ with highest mycelial inhibition $(87.77 \%)$ of Colletotrichum capsici and statistically significant over rest of the botanicals followed by Neem leaf extract which recorded mean colony diameter and percent mycelial inhibition of $17.00 \mathrm{~mm}$ and $(81.11 \%)$ and statistically significant over rest of the botanicals. Garlic bulb extract recorded colony diameter of $20.00 \mathrm{~mm}$ and corresponding inhibition of $77.77 \%$ and statistically at par with Tulsi leaf extract $(29.32 \mathrm{~mm}$ and $67.42 \%)$. It was statistically significant over rest of the botanicals. The Ginger rhizome extract $(31.33 \mathrm{~mm}$ and $65.18 \%)$ was statistically at par with Onion bulb extract which recorded $33.00 \mathrm{~mm}$ colony diameter and 63.33 inhibition. Karanj leaf extracts which recorded minimum colony diameter which was

$45.66 \mathrm{~mm}$ and $49.26 \%$ mycelial growth inhibition. The untreated control plates recorded maximum colony diameter i.e.; $(90.00 \mathrm{~mm})$.

Average mycelial growth least mycelial growth recorded by Neem leaf extract $(19.00 \mathrm{~mm})$ with highest percent mycelial inhibition (78.88\%) of Colletotrichum capsici over rest of the botanicals followed by Turmeric rhizome extract which recorded mean colony diameter and percent mycelial 
inhibition of $20.50 \mathrm{~mm}$ and $77.21 \%$ and statistically significant over rest of the botanicals. Garlic bulb extract recorded colony diameter of $33.66 \mathrm{~mm}$ and corresponding inhibition of $62.59 \%$ and statistically at par with onion bulb extract (34.83 mm and $61.29 \%$ ). It was statistically significant over rest of the botanicals. The Tulsi leaf extract and Ginger Rhizome extract recorded same average mycelial growth and percent inhibition (36.16 $\mathrm{mm}$ and 59.81\%). Karanj leaf extracts which recorded minimum average colony diameter which was $55.83 \mathrm{~mm}$ and $37.96 \%$ mycelial growth inhibition.

\section{Summary and Conclusions}

- All the two contact and six systemic fungicides evaluated in vitro were found fungistatic against Colletotrichum capsici. Among all these fungicides, Tricyclazole was found to be most effective with significantly maximum mycelial growth inhibition and least mycelial growth followed by fungicides viz. Azostrobin, Tebuconazole, Difenconazole, Propiconazole, Carbendazim + Mancozeb. While comparatively minimum average radial mycelial growth inhibition was recorded with Hexaconazole followed by Propineb

- All the seven fungal and one bacterial antagonists evaluated in vitro were found antifungal against Colletotrichum capsici exhibited significant mycelial growth inhibition. However, Trichoderma asperallum, Pseudomonas fluorescens, Trichoderma harzianum and Gliocladium virens recorded significantly highest mycelial growth inhibition. Rest of the bioagents, Trichoderma ligronum, Trichoderma koningii.

\section{References}

1. Saikia R, Padun A, Arora DK. Purification and characterization of toxins produced by Colletotrichum capsici, causing fruit rot in chilli. J Mycol. Pl. Pathol 2004;34(2):421-424.

2. Sangdee A, Sachan S, Khankhum S. Morphological, pathological and molecular variability of Colletotrichum capsici causing anthracnose of chilli in the North-east of Thailand. African J Microbiol. Res 2011;5(25):43684372.

3. Sawant IS, Narkar SP, Shetty DS, Upadhyay A, Sawant SD. First report of Colletotrichum capsici causing anthracnose on grapes in Maharashtra, India. New Disease Reports 2012;25:2.

4. Saxena A, Raghuwanshi R, Gupta VK, Singh HB. Chilli Anthracnose: The Epidemiology and Management. Frontiers in Microbiology 2016;7:1-18.

5. Saxena A, Sarma BK, Singh HB. Effect of Azoxystrobin Based Fungicides in Management of Chilli and Tomato Diseases. Proc. Natl. Acad. Sci., India, Sect. B Biol. Sci 2016;86(2):283-289.

6. Sharma P, Kulshrestha G, Gopal M, Kadu LN. Integrated management of chilli die back and anthracnose in Delhi region. Indian Phytopath 2004;57(4):52-55.

1. Sharma SG, Ram Narayan, Sangam Lal, Chaturvedi C. Role of phenolic compounds in resistance of maize to leaf blight caused by Drechslera state of Cochliobolus heterostrophus. Indian Phytopath 1983;36(1):43-46. 